\title{
The Color Purple: Reflections on The Second Sex and Gender Issues
}

\author{
Koyel Dasgupta \\ Department of English, Savitribai Phule Pune University, India \\ Email-koyeldasguptaa@gmail.com
}

Received: 02 Jan 2022; Received in revised form: 14 Feb 2022; Accepted: 22 Feb 2022

(C)2022 The Author(s). Published by TheShillonga. This is an open access article under the CC BY license

(https://creativecommons.org/licenses/by/4.0/)

\begin{abstract}
In this paper, we shall look at Alice Walker's The Color Purple in the light of Simone De Beauvoir's The Second Sex and analyse Celie's transformation from the 'Other' in De Beauvoir's terms to 'Self' in the course of the novel and how she grows up to speak for herself from being apparently silent under the oppression of her step-father and then her husband. We shall however question as to whether her 'voicelessness' can be considered equivalent to silence as she never stops from recording her experiences and emotions in her diary which is also a mode of expression. We shall also compare and contrast Celie, Shug, Sofia and Nettie in the light of The Second Sex. We shall also evaluate how Alice Walker has portrayed Celie's liberation from the domination of the men through the lesbian relationship between Shug Avery and try and briefly observe Walker's representation of the 'Black Lesbian'. Simone de Beauvoir has talked how women have been considered below man for centuries but we shall question in the light of the novel that how can we differentiate between the two genders and can that with which we are born in between the two legs- a phallus or a vagina be the sole criteria to determine who we are, what we should do, what we should wear and how we should behave or in other words can the phallus or the vagina only define our gender?
\end{abstract}

Keywords - Self, Other, oppression, liberating, transformation, Black Lesbian, gender, voicelessness, silence.

Our prime attention in this paper shall be to observe Celie's transformation from the 'Other' to the 'Self' in terms of Simone De Beauvoir' 'Self-Other' dichotomy in Alice Walker's The Color Purple and in the course of it analyze the other female characters- Nettie, Shug and Sofia according to the 'Self-Other' binary and look at some other aspects of the novel in the light of De Beauvoir's The Second Sex. We shall also look at how her lesbian relationship with Shug Avery liberates Celie and briefly at Walker's representation of the 'Black Lesbian' and finally question the differentiation of humans on the basis of the presence of a phallus or a vagina.

Simone De Beauvoir's pioneering text The Second Sex laid the foundation stones for the development of feminist theories in the Western Europe and America in the 1960s. In the illustrious introduction of her book, De Beauvoir states that Masculinity is fathomed as the "absolute human type" (16). She argues that women have over centuries been denied to exert their authoritarian selves when it comes to the question of formulating a decision about their own lives (Vintges 135). The central argument of The Second Sex is that women has always been considered to be the 'Other' whereas man has been the 'Self' or the subject and this has eventually led to the subordination of women throughout the cultural history. According to her, "He is the Subject, he is the absoluteshe is the Other" (Beauvoir 16).

Alice Walker's The Color Purple narrates the story of Celie, a young black girl who is repeatedly raped by a man who she addresses as ' $\mathrm{Pa}$ ' and who later is unbosomed to be her stepfather. This man takes away both of her children, pushes her into an unhappy and a loveless marriage and then she is also segregated from her beloved sister. Eventually, she meets the glamorous and flamboyant singer Shug Avery and her life changes, she gets transformed, her spirit gets liberated and the novel ends with Celie reuniting with those she loves including her sister and children.

Throughout the course of the novel, we meet Celie through her letters to God and to her sister Nettie. As a young girl who is raped, who fails to keep her children to herself, she truly appears as the 'Other', the subordinated one as compared to her stepfather Alphonso who is the 'Absolute'. Alphonso's 'Absoluteness' is so 
much, that he not only rapes Celie but also admonishes her "You better not never tell nobody but God...You better shut up and git used to it" (Walker 3) to which she acquiesces without a sigh, takes away Celie's children from her without a shred contrition, proscribes her from going to school and then pushes her into an oppressive marriage without any protest from anybody. De Beauvoir writes, “a woman's function is...to satisfy a male's sexual needs... These duties placed upon woman by society are regarded as a 'service' rendered to her spouse: in return he is supposed to give her presents, or a marriage settlement, and to support her" (416-17). In these terms since Celie is not his wife and therefore, Alphonso does not feel the urge to provide her with any gifts thereby completely disregarding the sexual gratification that he receives from her. However, De Beauvoir's argument somehow amalgamates 'marriage' and 'prostitution' where the woman is paid in return of her bodily services and in both she is treated as a 'sexual object'. The question that therefore arises is how different marriage is from the profession of the sex workers and are the social parameters that consider a sex worker to be 'undignified' or a 'bad woman' correct since whether marriage or sex work, for patriarchy, woman is an object who can satisfy man's carnal desires? Celie's mother and Alphonso's wife who is ill and therefore weak cannot engage into a sexual relationship with him is replaced by Celie who is now sexually exploited by him. Marriage even though it is deeply problematic somehow gives men a license to sexually exploit their wives even when she does to comply to get engaged into a sexual intercourse and as far the profession of sex work is concerned, it is the woman who is acknowledged as 'bad' and the man is never convicted. Therefore, as already discussed in De Beauvoir's terms, the give and take policy in both cases is socially 'legal'.

Alphonso has sexually abused or raped a child and therefore which is however, socially illegal, a crime for which he must be punished and thus, instead of offering her presents, he punishes her by precluding her from speaking about it to anyone, detaching her from her children and marrying her off. By virtue of these actions, he attempts to shield himself. After her marriage to the man whom she addresses to as $\mathrm{Mr}$ - in her letters and whose first name we later come to know from Shug is Albert, Celie continues to be the 'Other'. He does not love her and she is almost a slave to him whom he beats as per his caprices and when questioned by Harpo, his son as to why he beats Celie he replies, "Cause she my wife, Plus, she stubborn..." (Walker 23). This answer suggests as if marriage has issued for him a license to beat his wife and being 'stubborn' is not a womanly or a wifely virtue. The one who is the 'Other', the subordinate does not deserve to be or is expected to be 'stubborn'. Albert again expresses- "Wives is like children. You have to let'em know who got the upper hand" (Walker 35). Albert's notion of a wife is no less than a slave or a serf whom he can beat as per his whims. Also, the moment he considers a wife to be equal to a child he implicitly states that just like a child has to be controlled because she is too small to perform the right act, a wife must also be controlled because she can't be allowed to do anything according to her desire since she is incapable. This reminds us of Charlotte Perkins Gilman's "The Yellow Wallpaper" where John, the husband's narrator decides everything for his wife, the narrator

as to where she will live, what she will do which ostensibly looks like sweet gestures but are problematic since deep down those are attempts to subjugate her, control her and rendering her complete dependence on him. In her married life as well she is being commodified, exploited as a sexual object by her husband who does not care for her or her health or circumstance and does not possess even any exiguous trace of love for her. This is exemplified by Celie herself when she confesses before Shug- "He never ast me nothing bout myself. He calm on top of me and fuck and fuck, even when my head bandaged. Nobody ever love me, I say" (Walker 103). Here also she fulfils what De Beauvoir argues that "a woman's function is...to satisfy a male's sexual needs..." (416) as per the society's dictums. De Beauvoir writes, "History has shown us that men have always kept in their hands all concrete powers...they have thought best to keep woman in a state of dependence; their codes of law have been set up against her; and thus she has been definitely established as the Other" (159). In The Color Purple, Celie is truly economically dependent first on her step father and then on her husband at least in the initial stages of the novel. She has to depend on them for the three basic requirements of human life- food, clothing and shelter.

Celie's step father proscribes her from disclosing his sexual abuse of her to anyone which she truly doesn't except to God through her letters. Celie documents her feelings, her experiences with everyone she encounters in her letters first to God and then to her sister Nettie. What is important enough to be realized is that women have been silenced for centuries from expressing her desires, her feelings, her rights and Alphonso does the same thing when he says, "You better not never tell nobody but God. It'd kill your mammy" (Walker 3). His words sound like a presage which warns Celie that the transgression of this order from the 'Absolute' will result into menacing consequences. He threatens her with the possibility of her mother's death on her disapproval of his command. This 
echoes what the girls in Bengal were taught earlier- if they gain education, they will become a widow.

Illogical, unscientific and unjustified beliefs have always been attempted to be inculcated in women by the patriarchy to circumscribe her, dominate and subjugate her. Celie however, contravenes because she writes about her experience, treatment and condition in her letters addressed to God and we must realize that writing is indeed a mode of expression and Martha Culler claims, "the rape becomes not an instrument of silencing, but the catalyst to Celie's search for voice" (qtd. in Lewis161). The 'Self's' attempt to subjugate the 'Other' by silencing her is therefore not completely successful. Celie's description of the rape is quintessentially dismaying"First he put his thing up gainst my hip and sort of wiggle it around. Then he grab hold my titties. Then he push his thing inside my pussy. When that

hurt, I cry..." (Walker 3) What is even more grievous is when Celie says "I am fourteen years old. I am I have always been a good girl. Maybe you can give me a sign letting me know what is happening to me" (Walker 3 ). The definition of a "good girl" in patriarchal terms is discombobulating. The girl who abides by all the dictums of 'patriarchy' without questioning them is 'good'. But we know that this definition of 'good' is just another paraphernalia to dominate her. For Celie perhaps it is her adherence to whatever her Pa says, obeying the commands without questioning. Alphonso attempts to silent Celie again when he tells Albert that Celie "tell lies" (Walker 10). It is because he wishes to safeguard his inexpiable act and by assuring Albert that Celie can tell lies, he impregnates Albert's mind with the seed of disbelief so that even if Celie tells something, he does not trust her. A voice without acknowledgement is no less than silence. Celie's inner voice however gets recorded in her letters to which Alphonso is completely oblivious.

Sofia, who is Mr-'s son Harpo's wife appears to be fierce, strong and bold from the very first time that we come across her. She visits her sisters as per her wish even when Harpo says her that "she can't be all the time going to visit her sister. Us married now..." (Walker 35). Sofia refuses to be the 'Other' in her marriage, thwarts the possibilities of Harpo

dominating her and even on being invigorated by his father and Celie, when Harpo attempts to beat her, she does not behave like Celie and capitulate to her husband's tyranny but retaliates and Celie writes, "They fighting like two mens" (Walker 37). For Celie, a man can fight, he can beat his wife and when the wife also fights back her husband, she also becomes a 'man' in her comprehension. She expresses before Celie that even though she loves Harpo, she will "kill him dead before I let him beat me" (Walker 39). Even though Harpo like a patriarch expects Sofia to be as submissive as Celia and believes that "The wife spose to

mind" (Walker 61), Sofia firmly declares to not conform to his demands and tells Celie that "All he think about since us married is how to make me mind. He don't want a wife, he want a dog...He git up there and enjoy himself just the same. No matter what I'm thinking" (Walker 62), does not succumb to Harpo's oppression and leaves him. Sofia does not even accept the tyranny of the White Mayor and fights back when he slaps her because in his estimation a black cannot say 'no' to a white and Sofia even gets imprisoned for this. Sofia epitomizes strength, resoluteness, indomitableness and intrepidity as compared to the exploited Celie of the initial stage of the novel who does not fight back her tormentors. Sofia in her marriage is not the 'Other' not even later when she reconciles with Harpo and she repudiates De Beauvoir's 'Self-Other' paradigm and emerges as the 'Self' of her own life.

When Nettie says to Celie that she is not dumb even though their $\mathrm{Pa}$ believes and professes before Albert otherwise and then when Nettie instructs Celie about Albert's children that "Don't let them run over you...You got to let them know who got the upper hand...You got to fight. You got to fight" (Walker 18) we discern that she is not the one who can be easily subdued or vanquished. Even though the libidinous Albert advanced towards her, as she explains to Celie in the first letter, he failed to subjugate her, she fought him and even injured him. As the story propels forward, we witness a Nettie who grows up to be stronger, compassionate, loving and a second mother to Adam and Olivia after Corrine.

Nettie continues to be the 'Self' and since she does not marry the question of the 'Self-Other' dichotomy does not arise. However, after getting married to Samuel, there occurs no reference which can galvanize us to think that De Beauvoir's notion preponderates their relationship.

Shug Avery is a singer; she is economically independent. She is the master of her own destiny, she is Albert's mistress but when Albert says, as Celie writes, “My wife can't do this. My wife can't do that. No wife of mines...He go on and on" (Walker 69) she spontaneously replies, "Good thing I ain't your damn wife" (Walker 69). It is with Shug's help that Celie discovers Nettie's letters for her which Albert had hidden from her for years. The most important aspect that is to be observed is that Celie learns that Alphonso is not their 
Biological father from one of Nettie's letters- "Pa is not our Pa!" (Walker 159). When she learns that her black father was lynched and killed along with his three brothers, Celie questions what has God done for her and decides to address her letters to her sister Nettie and no more to God. This is perhaps because she thinks that God did not let her have her own loving father and instead incorporated a despicable man in her family who became her father, her $\mathrm{Pa}$ whereas Nettie reveals that her real father was someone else and the man who raped her, separated her from her children and oppressed her is not her father. She therefore decides to write to someone whose letter has annihilated her father-daughter relationship with that contemptible man and not to someone who brought him into her life as her father. Shug possesses a disposition that cannot be moulded by patriarchy. Shug's conception of God is inordinately unconventional and quintessentially 'modern'. When Celie says, "You telling me God love you, and you ain't never done nothing for him? I mean, not go to church, sing in the choir, feed the preacher and all like that?" (Walker 174), Shug replies,

But if God love me, Celie, I don't have to do all that. Unless I want to. There's a lot of other things I can do that I speck God likes...Oh, she say. I can lay back and just

admire stuff. Be happy. Have a good time... She say, Celie, tell the truth, have you ever found God in church? I never did. I just found a bunch of folks hoping for him to show. Any God I ever felt in church I brought in with me. And I think all the other folks did too. They come to church to share God, not find God (Walker 174).

Shug is a woman who exhibits the courage to even humanise God, therefore Shug allowing the patriarchal society or the men in her life to subjugate her is outlandish. Shug's further words illuminate that how racism has infiltrated even ideas about God, how God is portrayed before us to be only white

Then she tell me this old white man is the same God she used to see when she prayed. If you wait to find God in church, Celie, she say, that's who is bound to show up, cause that's where he live...Shug! I say. God wrote, white folks had nothing to do with it. How come he look just like them, then? She say. Only biggest...Ain't no way to read the bible and not think God white, she say. Then she sigh. When I found out I thought God was white, and a man, I lost interest. You mad cause he don't seem to listen to your prayers. Humph! Do the mayor listen to anything coloured say? Ask Sofia, she say (Walker 175).

What we need to understand is that the moment someone who is black, conforms to what has been conventionally believed that God is white-skinned, $\mathrm{He}$ will seem to be distant and since the whites consider the blacks as inferior like the patriarchal society conceives women to be inferior, He will not be unimpeachable and trustworthy because he will not appear magnanimous but oppressive like the whites who never listen to the Blacks. Therefore, how can someone who is Black pray to Him or expect her prayers to get answered? We must also remember what Nettie has written in one of her letters"All the Ethiopians in the bible were colored...It is the pictures in the bible that fool you. The pictures that illustrate the words. All of the people are white and so you just think all the people from the bible were white too. But really white white people lived somewhere else during those times" (Walker 120). Racism has even contaminated the domain of religion and as Shug says, if a black attempts to seek God following the dictums formulated by the whites, the attempts will be nugatory. Shug continues, "The thing I believe. God is inside you and inside everybody else. You come into the world with God. But only them that search for it inside find it...I believe God is everything, say Shug. Everything that is or ever was or ever will be. And when you can feel that, and be happy to feel that, you've found it..." (Walker 176). Shug's words echo Rilke's conception of God as his Letters to a Young Poet exemplifies where he argues that God is the Absolute, the Ultimate and the sorrow, affliction and pain that we feel is because of the pregnancy that will follow the arrival of $\operatorname{God}^{1}$. This notion emphasizes that we participate in a process that is Divine, a process whose end result is the advent of God. The participation in a Divine process and the idea that God resides in every human being both approximate us to God, makes Him earthlier rather than mystical or transcendent. Shug's words intensify one idea that Celie herself proclaims- "You mean it want to be loved, just like the Bible say" (Walker 177). Shug's injunctions about God humanises the Almighty, brings him closer to humans and therefore, we are reminded of Rilke's "Pieta" where he portrays Jesus Christ as a humanised figure and amalgamates Mary Magdalene's spiritual as well as sexual love for Jesus, which is archetypally unconventional. Simone De Beauvoir writes, "St. Paul enjoyed self-effacement and discretion upon women; he based the subordination of woman to man upon both the Old and the New Testaments. 'For man is not of the woman; but the woman of the man. Neither was the man created for the woman; but the woman for the man'. And 
in another place: 'For the husband is the head of the wife, even as Christ is the head of the

${ }^{1}$ From the chapter "Letter 6" Rainer Maria Rilke, 2011, Letters to a Young Poet, translated by Charlie Louth, UK: Penguin Classics.

church... Therefore as the church is subject unto Christ, so let the wives be to their husbands in everything", (120). De Beauvoir also refers to St Thomas' ordinance- "...he declared that woman is only an 'occasional' and incomplete being, a kind of imperfect man. 'Man is above woman, as Christ is above man', he writes" (121). Gender discrimination has also adulterated religion and concepts about God along with racism and Shug rescinds the gender disparity like she abrogates racism by just saying- "Yeah, It. God ain't a he or she, but a It" (Walker 176). By this single statement she questions all the patriarchal ideas that if God is genderless, who has given us the audacity to acknowledge one gender to be superior to another and that too by drawing an analogy to Christ himself? Shug thwarts the possibility of being the 'Other' in both her relationship with Albert as well as with her husband Grady because she can boldly answer back Albert and while being married to Grady, she makes her own decisions. Shug is the 'Self' of her life, she decides her own actions. We shall explore Shug more when we discuss Celie's relationship with her and her appreciable influence in Celie's life.

As compared to Celie, the other three women are in better position- they decide for themselves, do not let others to subjugate them. However, we have to realize one very important aspect- the way the four important characters- Celie, Shug, Nettie and Sofia were brought up. In A Vindication of the Rights of Women, Mary Wollstonecraft writes that women

have naturally, that is from their birth, independent of education, a fondness for dolls, dressing, and talking, they are so puerile as not to merit a serious refutation. That a girl, condemned to sit for hours together listening to the idle chat of weak nurses or to attend at her mother's toilet, will endeavour to join the conversation, is, indeed very natural; and that she will imitate her mother or aunts, and amuse herself by adorning her lifeless doll, as they do in dressing her...is undoubtedly a most natural consequence... and by this she means that everything as to how we shall behave and act are determined by the way we are brought up. Women are made to believe that "beauty is woman's sceptre..." (Wollstonecraft). Virginia Woolf also writes that the societal opinion that women are inferior was reiterated and eventually this belief was inculcated in women so that they were also made to believe that they are inferior. In The Color Purple, Sofia tells Celie that "All my life I had to fight. I had to fight my daddy. I had to fight my brothers. I had to fight my cousins and my uncles. A girl child ain't safe in a family of men..." (Walker 39)Sofia and as she says all her sisters have learnt to fight since their childhood and therefore, when Harpo, her husband attempts to dominate her and beat her she fights back. Virginia Woolf in A Room of One's Own complains that women don't get equal opportunities as men and she narrates the tale of Judith Shakespeare, William Shakespeare's imaginary sister who even though was born with equal talent and creativity as her brother was denied of the opportunities because of her gender whereas, these opportunities made her brother what we know him today to be.

Nettie meets Samuel and Corrine and then gets the opportunity to get educated and to work as a missionary which restructures her life and intercepts her from suffering. Celie on the other hand neither learnt to fight since her childhood nor she got the opportunities like Nettie nor she was financially independent as Shug. But when she finally gets the opportunities, she emerges to be victorious stamping all the evil forces that hitherto attempted to hegemonize her.

Celie gets pregnant twice by her step-father even before she could comprehend pregnancy or motherhood which is why she never says that "I am pregnant" but just "I'm big. I can't move fast enough" (Walker 4). Her inability to expound her condition (pregnant) as a child is even more disconcerting. Alphonso's acts commemorate what De Beauvoir argues women are taught since infancy- "From infancy woman is repeatedly told that she is made for childbearing..." (473) and fabricate a childhood of nightmare for Celie. The births of her children extirpate the child within her. Alphonso's act compels Celie to believe that child bearing and the act of giving birth to them are something which discriminate and dedicate themselves to gormless and glaikit women and girls. She is therefore perplexed when she hears that the girl Harpo intends to marry which is Sofia is pregnant and in an innocent tone asks "If she so smart how come she big?" 
De Beauvoir argues, "The common story is one of seduction...It is often the seducer himself who convinces the woman that she must get rid herself of the child..." (470-71). In Celie's case, Alphonso is not solely a seducer but the 'Absolute' which is why he does not feel the compulsion to 'convince' Celie to get rid of her children but directly takes away her children thereby complying to his selfish interests.

According to De Beauvoir, a man "thinks of his body as a direct and normal connection with the world, which he believes he apprehends objectively, whereas he regards the body of woman as a hindrance, a prison ... Woman has ovaries, a uterus; these peculiarities imprison her in her subjectivity, circumscribe her within the limits of her own nature" (qtd. in Habib 683). In terms of Biological Science, the ovaries and the uterus are organs of the female reproductive system which facilitates in giving birth to a new life. De Beauvoir argues that contraceptives unshackled women from the "slavery of reproduction" which she believes to be a harbinger of the dawn that shall mark the commencement of equality for women (qtd. in Habib 689) Celie's reproductive system after her sexual exploitation by Alphonso also corroborated the births of a son and a daughter. However, Alphonso's act of separating the children from their mother and the termination of Celie's monthly menstruation can be considered in terms of De Beauvoir as liberating her from the constraints thrusted upon her by her reproductive organs or reproduction since the monthly bleeding \{ De Beauvoir calls it the "monthly "curse"" (59)\} which signalises a woman's potency to give birth to a child stops in her case and confirms that Celie can never reproduce The cessation of her menstrual cycle at a much early age act as contraceptives for Celie. Children are the final products of a reproductive process and when De Beauvoir consider that 'reproduction' is an impediment for women this means that she unequivocally comprehends children to weave hindrances for women. When she argues, "As for the burdens of maternity, they assume widely varying importance...they are crushing if the woman is obliged to undergo frequent pregnancies... but if she procreates voluntarily and the society comes to aid her during pregnancy...the burdens of maternity are light..." (7980 ). We have to agree with De Beauvoir that continuous pregnancies must be condemned because that can be burdensome and moreover, they make her weak and her health deteriorates. In that way contraceptives have been indeed revolutionary in saving women from this but again she mentions that the burden of maternity even though it is light "if she procreates voluntarily"
(80), is still an encumbrance, a burden. De Beauvoir looks at maternity from one perspective thereby completely snubbing the aspects of love and affection that it encompasses. In the novel, we never find Celie apprehending that her children formulate any kind of limitations for her. On the contrary, she laments at their loss- "He took it while I sleeping. Kilt it out there in the woods...He took my other little baby, a boy this time" (Walker 4). Later when Celie sees her daughter and claims her to be "mine" the tone of love and attachment is unmistakable- "I seen my baby girl. I knowed it was her...I think she mine. My heart say she mine" (Walker 15). The repetition of "mine" pellucidly portrays her love for her child. Also, like a mother she attempts to protect her sister Nettie from the concupiscent Alphonso- "I see him looking at my little sister. She scared. But I say I'll take care of you" (Walker 5). The last statement echoes a motherly assurance where she can go to any extent to guarantee Nettie's safety. At the end of the novel Celie is overwhelmed to finally meet her children and hugs them with the motherly affection which can be assumed even though it is not explicitly stated. Therefore, we can question as to whether reproduction or children is something which Celie perceives as a source which constrains her? The answer to this is perhaps not. Thus, De Beauvoir's notions are probably not applicable for every woman. Also, Pilardi tells us that "Commentators...especially disliked her ideas about maternity; this included both her denial of the existence of a 'maternal instinct' -her claim that because of their reproductive systems women were the victims of the human species -and her descriptions of the difficulty and ambivalence of motherhood for human females" (60-61). However, we cannot be sure as to what would Celie have felt if she had to raise her children and her menstruation had not stopped which could have ensured the birth of more children due to her sexual exploitation by Alphonso and later by Albert. Nettie writes in one of her letters, "The Olinka do not believe girls should be educated. When I asked a mother why she thought this, she said: A girl is nothing to herself; only to her husband can she become something. What can she become? I asked. Why, she said, the mother of his children" (Walker 140) and this echoes De Beauvoir's argument that "From infancy woman is repeatedly told that she is made for child bearing, and the splendours of maternity are forever being sung to her" (473). Nettie's reply overwhelms us- "But I am not the mother of anybody's children, I said, and I am something" (Walker 140) since through this one statement Walker perhaps ventures to vindicate that 'femininity' or rather the 'identity of a woman' cannot 
incontrovertibly be determined by her ability to give birth to children. Also, Nettie never gives birth to any children but continues to be a mother figure for her sister's children and demonstrates that motherhood cannot only blossom when one gives birth to a child. Sofia and Shug are also mothers but their 'reproduction' never circumscribe them or hinders them to act in the way they desire. By the time the novel was published, occurring to a girl of fourteen was freakish but then as already discussed Celie had her permanent natural contraceptive through the termination of her menstruation.

It would be wrong to say that only Shug contributes to Celie's metamorphosis from the 'Other' to the 'Self'. The foundational stone is laid when she is envious of the fact that Harpo fails to dominate Sofia in the way that Albert does her and this is exactly why she advocate Harpo to "beat" Sofia. What we must realize here is that Celie's jealousy unambiguously stems from her perception that the way Mr- treats her is not 'right' and she is wronged and she could not bear that Sofia cannot be subjugated whereas she can be. Celie must have realized that domination and subjugation of a human by another human is not 'natural'. After losing Nettie, if not a sister or a friend but Celie finds a companion in Sofia with whom she asservated her desire to "make quilt pieces out of these messed up curtains" (Walker 41) and this renders her a sense of

When two women get involved in a love relationship they are referred to as lesbians. 'Lesbian Literature' explores the lesbian themes and 'Black Lesbian Literature' is a sub- genre of the lesbian literature and African American literature which concentrates and emphasizes on the experiences of black women who are acknowledged as lesbians. Alice Walker's The Color Purple is about the diverse experiences of Celie, a black American woman and therefore the novel can be categorised under 'Black Lesbian Literature'. We shall now see how Walker has portrayed Celie's 'Black Lesbian' relationship and what role it has played in her life in the novel. Shug's companionship with her as a friend and as a lover plays the most significant role in liberating her and thereby with her, Celie completes the process of her transformation to the 'Self' in her life. On Shug's advice, Celie looks at herself for the first time and touches herself and that is a sexual touch. When she expounds her experience-

I lie back on bed and haul up my dress. Yank down my bloomers. Stick the looking glass tween my legs. Ugh. All that hair. Then my pussy lips be black. Then inside look like a wet contraceptives were available in America and knowing the kind of women Shug and Sofia are, we can perhaps conclude that they have access to the contraceptives which empowered them to "procreate voluntarily" (De Beauvoir 80). When Celie got pregnant twice, she didn't even understand what it was and therefore the idea of using contraceptives

contentment which is why "I sleeps like a baby now" (Walker 41). Celie's attempt to create quilt pieces out of the 'messed' curtains ignites a hope that this is the beginning of the process of reorganising and settling her own life which is a mess because of the men in her life. Celie takes the next step in the process of her metamorphosis when she silently punishes Old Mr- or Albert's father by dropping "little spit in Old $\mathrm{Mr}$ water" (Walker 52). This is because she realizes that Old Mr- mortifies her by saying "She black as tar, she nappy headed. She got legs like baseball bats" (Walker 52). We can apprehend that Celie has commenced discerning that no one possess the authority to make contumelious comments on the basis of her skin colour or her physical looks. This is even more perspicuous when we refer to Alphonso's deprecatory comments about Celie- "She ugly...She ain't smart either...You too dumb to keep going to school" (Walker 11) but then Celie's protest was limited to writing about it to God in a letter whereas now she does not just write but acts.

rose. It a lot prettier than you thought, ain't it? She say from the door. It mine, I say. Where the button? Right up near the top, I say. The part that stick out a little. I look at her and touch. But just enough to tell me this the right button to mash. Maybe. She say, While you looking, look at your tittties too. I haul up my dress and look at my titties. Think bout my babies sucking them. Remember the little shiver I felt then too (Walker 75).

We realize that Celie now enjoys that sexual pleasure herself with her own body which hitherto was enjoyed by Alphonso and Albert only but not herself and Shug becomes the one to direct her. Celie's bonding with Shug gradually matures into a sexual intercourse in the absence of Albert and Shug's husband, Grady and the experience of sensual delight and the bodily discourse are enjoyed by both. Celie and Shug become a paragon of a sexual relationship where there is dependency, vulnerability and most importantly equality. Shug and Celie's relationship is the paradigm of Walker's representation of the 'Black Lesbian'. "Together, black lesbian and lesbian-allied writers cultivated what" (Lewis 159) Christopher 


\section{S. Lewis' article}

calls 'black lesbian shamelessness,' an amended version of the calls for black pride that circulated in the Black Power and Black Arts Movements. Black lesbian shamelessness is defined by its celebration of the fact that same-sex relationships sustain and nurture the lives of countless black women, as well as by its acceptance of vulnerability and mutual dependence as fundamental conditions of human relationship (qtd. in Lewis 159).

Celie's lesbian relationship sustains her, emboldens her to love herself and develops her to be strong enough to fight for herself. What is more important is that chaperoned by Shug, she finds Nettie's letters to her which till date were hidden from her by Albert. The cultural obligation that demanded black women ceding their sexual articulation was critiqued by the 1970s and 1980s Black Lesbian writers (Lewis 161). The inefficaciousness of this was documented by Audre Lorde via silence in her "The Transformation of Silence into Language and Action" in which as Lewis explains,

Lorde asks that black lesbians in particular liberate themselves from the operating presumption that their silence on issues of same-sex desire can protect black people in general from heterosexist and/or racist judgment. Her suggestion that, had she been mute, she 'would still have suffered' resounds because (black) women are violated in patriarchal cultures regardless of their sexual experience, expression, clothing, make- up, or any other defining feature of propriety (161).

Celie has been silenced since her adolescence by Alphonso. She was allured by even the name of Shug Avery but never professed that and her expression of her emotions was limited to her letters to God. It is in Shug's companionship that she speaks out. Shug speaks out her name and what more she even sings a song for her"Then I hear my name. Shug saying Celie. Miss Celie...She say my name again. She say this song I'm bout to sing is call Miss Celie's song. Cause she scratched it out of my head when I was sick. First she hum it a little, like she do at home" (Walker 70). Then Celie writes, "I look at her and I hum along a little with the tune. First time somebody made something and name it after me" (Walker 70). She participates with Shug and the fact that somebody is speaking or singing for her probably acts as a stimulation for her to speak out and in the very next letter we see Celie telling Shug- "He beat me when you not here, I say" (Walker 71). She has a tone of complaint and this is the very first time that she complaints against a wrong that is inflicted upon her to a person and not just God and we realize that this indeed is the exordium of Celie's liberation process. We can agree to Lorde's dictum that not just Celie's sexuality but her gender also is the reason of her oppression and what is even more important is that none of her oppressors were cognizant that she is a lesbian but she has been tyrannised. This reminds us of what Gomez says, "Black lesbians, feeling triply targeted as Black, female, and lesbian (each of which also is affected by class), have perspectives that may compete with one another for literary and political focus" (951). We need to realize that even though Celie speaks about Albert's brutality to Shug she is not absolutely enfranchised from the impediments. When Shug and Celie get engaged into a sexual intercourse and then fall asleep, the arrival of Albert and Mr Grady, awakens Celie and she in turn arouses Shug- "Wake up Sugar, I say. They back..." (Walker

104) and Shug gets up hugs her and goes back to her room. The tone of circumspection so that they do not get caught is implicit in Celie's words which suggest that she does not desire for others to discover that they are in a lesbian relationship. Towards the later part of the novel however, she is no more afraid to express her love for Shug even in front of Albert.

Wilson argues, "Within lesbian sexual culture, gendered sexual discourses have illuminated the myriad ways that lesbian women have used and expected one another to identify with labels along masculine and feminine continua; terms like 'femme' and 'butch' are among the labels that lesbians have used to describe where they fall along these continua" (298). In one of her letters Celie writes, "That when I notice how Shug talk and act sometimes like a man. Men say stuff like that to women, Girl, you look like a good time.

Women always talk bout hair and health. How many babies living or dead, or got teef" (Walker 77). We wonder whether we can identify Shug as 'butch' which Celie's account that she at times talk and act like a man urges us to think. Simone De Beauvoir argues, "Two types of lesbians are often distinguished: the 'masculine' who 'wish to imitate the male', and the 'feminine' who 'are afraid of the male"" (398). Wilson argues, "Historians have noted gender nonconforming modes of expression as core features of sexual life among Black same-gender loving women in the USA since the 1920s (Garber 1989; Walker 2001)" (qtd. in Wilson 299). Shug Avery does not conform to all the societal womanly characteristics. She is outspoken, so much so that she can boldly confront her lover and say that that its 
good that she is not is wife, she also assures Celie to be her protector- "I won't leave, she say, until I know Albert won't even think about beating you" (Walker 72), she facilitates Celie to get to know herself; discover and acknowledge herself in a way that she herself hitherto was oblivious to; liberate her from her contemptible circumstance; stand up for herself and then prepares her to become financially independent. Society don't expect a woman to do these especially a woman to be a protector for someone as this is something which a man becomes. The conventional belief is that, as the fairy tales teach us that the Prince Charming will come to rescue the damsel in distress from her egregious and diabolical condition and become her lifelong protector. We are therefore reminded of De Beauvoir's argument that "The truth is that man today represents the positive and the neutral- that is to say, the male and the human

being- whereas woman is only the negative, the female. Whenever she behaves as a human being, she is declared to be identifying herself with the male" (398-99). Shug behaves, speaks and acts in a way that the patriarchal society proscribes a woman to do and therefore Celie thinks she acts and talks like a man when the truth is that Shug behaves as a human being, the way a normal human should behave and the way the society should have expected humans irrespective of their genders to behave. "The term 'femme' continues to be used in Black same-gender loving communities to denote women who identify as feminine in appearance, behaviour, erotic expression and/or relationship roles" (qtd. in Wilson 298). De Beauvoir also writes as we have already seen that the 'feminine' in a lesbian relationship is who is afraid of the man (398). Since Celie herself acknowledges Shug more like a man we therefore, question whether she is the 'femme' or 'feminine' in this relationship? However, Shug wears dresses too that are conventionally comprehended to be for 'women' as does Celie and we must remember that Celie has never been frightened for herself. She has been afraid for her mother's death, her sister and even though ostensibly she has appeared to be weak and vulnerable in front of Alphonso and Albert's tyranny and has never protested verbally, we must never forget for a moment that she has extensively written about her oppression in her letters, she has expressed it even though she was interdicted by Alphonso from saying about his felonies to anyone and even silently punished the one who said humiliating words about her (Albert's father). Eventually she learns to speak out too. She tells Shug about her rape by Alphonso at an age she didn't even understand what was happening, about Albert's complete disregard for her and her sexual persecution even by Albert. We must also remember that she never felt the delight in a bodily discourse previously-

You like to sleep with him? I ast. Yeah Celie, she [Shug] say, I have to confess, I just love it. Don't you? Naw, I say. Mr- can tell you, I don't like it at all. What is it to like? He git up on you, heist your nightgown round your waist, plunge in. Most times

I pretend I ain't there. He never know the difference. Never ast me how I feel, nothing. Just do his business, get off, go to sleep...You never enjoy it at all? she ast, puzzle. Not even with your children daddy? Never, I say (Walker 7374).

She was sexually exploited by both men; those were sexual relationships that were devoid of love and the possibility of 'enjoyment' does not even arise. But with Shug, as Celie herself expresses, "It feel like heaven is what it feel like, not like sleeping with Mr- at all" (Walker 104). This is because there is love and equality in her sexual relationship with Shug. Celie's relationship with Shug liberates her and then she verbally protests against Albert for the first time when he humiliates her by saying-

Shug got talent, he say. She can sing. She got spunk...She can talk to anybody. She got looks... She can stand up and be notice. But what you got? You ugly. You skinny. You shape funny. You too scared to open your mouth to people. All you fit to do in Memphis is be Shug's maid...A man try to be nice to you, you fly in his face (Walker 186)

and to this Celie sharply retorts, "I curse you...Until you do right by me, everything you

touch will crumble" (Walker 187). Albert now says, "You black, you pore, you ugly, you a woman. Goddam, he say, you nothing at all" (Walker 187). Albert attempts to marginalise her on the basis of her gender, skin colour, countenance but Celie does not stop this time and goes on cursing him and it seems that she trounces him completely when she proclaims, "I'm pore, I'm black, I may be ugly and can't cook, a voice to everything listening. But I'm here" (Walker 187). Celie's retaliation vivifies that now she is unstoppable in the process of her liberation because she has learnt that she can lack certain things (according to the societal norms) but that don't make her any less of a human and now she proudly professes that. This realization that she is a human who has significance, that she may not be important to others but she is to herself elevates Celie from all her affliction and agony. Celie's visit to Memphis completes her process of liberation as Shug says, "You not my maid. I didn't bring you to Memphis to be that. I brought you here to love you and help you get on your feet" (Walker 191). Celie starts making pants and after making one for Shug, then Squeak, 
then Jack, then Odessa and then "Shug want two more pair just like the first. Then everybody in her band want some. Then orders start to cone in from everywhere Shug sing..." and finally when Shug says, "You making your living, Celie, she say. Girl, you on your way" (Walker 193) and we know that this economical independence will liberate Celie completely for now she has learned to discern her importance as a human being regardless of everything, she can raise her voice for herself and love and engage in a sexual intercourse according to her desires. Her delectation and felicity are evident when she writes, "I am so happy. I got love, I got work, I got money, friends and time..." (Walker 194) to Nettie. 'Work' completes her process of liberation and we are therefore reminded of De Beauvoir's dictum-

Two essential factors paved the way for women's prospective equality: one was her ability (conferred by technology, which abrogated any innate male advantages of strength) to share in productive labor; and the second was her recently acquired freedom from the slavery of reproduction through contraception, adopted by many of the middle and then the working classes from the eighteenth century onward (qtd. in Habib 689).

We are exclusively emphasizing on the first factor here as Celie's pants are the end result of her "productive labor". In A Room of One's Own, Virginia Woolf also advocates for the need for women to be financially independent"...a woman must have money and a room of her own if she is to write fiction" (Woolf 7). We can however question that can only financial independence earn equality for women because even when she is not economically dependent, she is expected to look after the family and children which the man need not?

This is something which is very much prevalent in contemporary society as well and De Beauvoir also says that, "Woman was now almost in a position to assume a role of economic independence. And yet, a major factor retarding her freedom was the continued existence of the family, sanctioned by the various ideologies - political and religious - which aimed to detain her in her traditional roles" (qtd. in Habib 689). Although Celie is not belligerent to a family and yearning to meet her children and her sister as she says, “. I got love, I got work, I got money, friends and time. And you alive and be home soon. With our children" (Walker

194) yet we are apprehensive as to whether all these will be enough to formulate equality for her? We know that even in contemporary times the scenario has not changed however, a vibe of equality overwhelms us when we Celie writes about her and Albert- "Now us sit sewing and talking and smoking our pipes" (Walker 247) (sewing is a job that the society expects women to do). De Beauvoir argues that being a mother is what the society believes defines women- "It is in maternity that woman fulfils her physiological destiny..." (467). Celie invalidates this by fulfilling her physiological destiny in setting up her own business, working for it and becoming an entrepreneur. She is a mother but she cannot be defined as only Adam and Olivia's mother or Albert's wife for that matter or a black woman but as a human and as an entrepreneur. She is therefore, no more the 'Other' but the 'Self' of her own life. The men in her life have always "defined her choices" (qtd. in Habib 689) from separating her from her children to getting married to Albert but now she chooses for herself and her transition from 'Other' to 'Self' is therefore complete. Shug has already explained that she perceives God to be genderless and now when Albert asks "what was so special bout my pants" (Walker 246), Celie replies "Anybody can wear them" (Walker 246) and through her pants she attempts to erase the disparities between humans on the basis of gender. Together Shug and Celie epitomize, “...Taylor and Rupp argue that one of the most significant forms of US second-wave feminist ritual that have characterized contemporary lesbian culture is the androgynous or 'neither masculine nor feminine' mode of self-presentation" (Wilson 298) and even De Beauvoir says that this distinction between lesbians as 'masculine' and 'feminine' "seems to" her "rather arbitrary" (398). Therefore, it is better if we don't endeavour to categorize one of them as "butch" and the other as "femme" but just consider them as two humans who are in love. Walker, through her portrayal of the Black Lesbian through Celie- Shug delineates equality irrespective of gender, skin colour and everything else. Walker portrays how love and support can chaperon one to grow, develop and not to forget liberate from all constrains. Walker illustrates a relationship through her portrayal of the Black Lesbian in which the superiorinferior dichotomy is absent and which she adduces to prove that subjugation of one by another by an equal treatment of one another is what defines a love relationship. And lastly, love has no gender like Shug's God and Celie's pants. We are therefore reminded of Deepa Mehta's Fire, where the two women, Sita and Radha, are caught up in unhappy marriages. Sita's and Radha's sexual desires remain unfulfilled because Sita's husband has an extra-marital affair and has no bonding with Sita either at emotional or at the physical level and Radha's husband refuses to have a sexual intercourse with her because she is infertile and the 'Swamiji' has instructed him that, sexual relationships are only meant 
for procreation. Both the women are imprisoned in the household and eventually finds solace in each other's emotional and sexual love which liberate them both.

Barbara Smith writes, "The use of Black women's language and cultural experience in books by Black women about Black women results in a miraculously rich coalescing of form and content and also takes their writing far beyond the confines of white/male literary structures" (23). In The Color Purple, Alice Walker has portrayed the experience of Sofia as to how she suffered for just being a black woman and showing the audacity to say a no to a white man. We realize that Sofia is just the medium and this is something that African- Americans have faced in The USA because of their skin colour and in women's case, their gender as well. When Albert abuses Celie, he uses both "black" and "woman" as if those are abusive words, 'bad' words but Celie's sharp retort, emphasizes that these do not make her any less in anyway, these are not abusive, she is contented with what she is, and most

importantly these are not 'bad'. But we realize that through Celie, Walker manifests how these were actually abusive terms in America. The novel uses what is called "African American Vernacular English (AAVE)" in which Celie has written the letters and which has portrayed her emotions and experiences even more strongly. The refusal to use the 'polished' English language of the White Americans has also been a way of protest and Walker thereby conforms to Smith's articulation that black women's language as well as cultural experiences must be limned in books about black women by black women. "Henry Louis Gates, Jr. championed The Color Purple for revealing that 'one can write an entire novel in dialect', which in turn affirmed that AAVE itself was a 'storehouse of [linguistic] figures' rather than an unsophisticated or simplistic sublanguage" (qtd. in Lewis 166).

During one of their conversations, Albert tells Celie, "He say to tell the truth, Shug act more manly than most men. I mean she upright, honest. Speak her mind...Just like Sofia. She bound to live her life and be herself no matter what" (Walker 244). Now Celie writes, "Mr- think all this is stuff men do... What Shug got is womanly it seem like to me..." (Walker 244). and she the writes that Albert says, "Sofia and Shug not like men, he say, but they not

like woman either" (Walker 244). Albert himself propounds that Sofia and Shug cannot be categorised either as a man or as a woman. Sofia can fight like a man with Harpo but she has her children, she can even care for children those are not hers; Shug we have already discussed extensively exhibit conventionally 'manly' characteristics but she like a woman has also given birth to children, married a man, been into a relationship with Albert willingly, wears gown like women; Celie is also a mother, a wife which are meant to be for women but then she protests against her husband's humiliation of her, curses him which a woman is not supposed to do and Albert who appears to be a prototype of the patriarchal husband who exploits, beats and tyrannises his wife at the beginning is seen to be sewing with her towards the end of the novel which is stereotypically a 'womanly' job when he becomes friends with Celie. Therefore, there is one question that we can ask- how can we differentiate between the two genders and can that with which we are born in between the two legs- a phallus or a vagina be the sole criteria to determine who we are, what we should do, what we should wear and how we should behave or in other words can the phallus or the vagina only define our gender? Only when we perceive their traits as 'human' and not as 'manly' or 'womanly', does all our qualms dissolve. These characters and the 'adulterated' disposition that they possess questions our comprehensions about gender and hints that not our phallus or vagina but our actions define us, not as a man or a woman but as a human and these are what we must endeavor to be- a human who can fight for 'it's' rights, be independent, not submit to oppression, not tyrannise or exploit or dominate another fellow human being on the basis of anything, knows to love, care and support. As Shug and Sofia have consistently corroborated that their vagina cannot decide their penchant to do something or act in a stereotypical 'womanly' way, so must be the truth for others. Our phallus or vagina cannot and should not decide our proclivity to do or wear something; to behave is a certain way or to take up a profession. Both the phallus and the vagina participate in the reproductive process but only the one with the vagina reproduces the baby. But this does not mean just because that human can give birth to a new life or just because the other cannot, it can define their ways of life.

This is only possible when the society as a whole learns to rescind the patriarchal rules and treat everyone not as a man or a woman but as a human who has the right to get equal opportunities in every realm.

\section{CONCLUSION}

Thus, we could observe Celie's transformation from the 'Other' to the 'Self' of her life in the course of the novel and analyse the other women in the novel according to the Self-Other binary. African-American women face a double marginalization because of their skin color and also 
because of their status as women but in the novel, we observe black women supporting and being there for one another and how Shug and Celie's lesbian relationship liberated Celie from her hitherto constraints. 'Black Lesbian' becomes extremely powerful in freeing a woman thereby challenging societal frown against same sex relationships and the Whites consideration of the Blacks as inferior. We have also attempted to try and answer the question- "How can we differentiate between the two genders and can that with which we are born in between the two legs- a phallus or a vagina be the sole criteria to determine who we are, what we should do, what we should wear and how we should behave or in other words can the phallus or the vagina only define our gender?" and concluded that no, the phallus and the vagina cannot determine all these. Through this paper we have attempted to question the conventional notions of gender and how they can be re-evaluated and re-comprehended.

\section{REFERENCES}

[1] Beauvoir, Simone De. (1956). The Second Sex. Translated and edited by H.M. Parshley, Jonathan Cape.

[2] Gilman, Charlotte Perkins. (1999). The Yellow Wallpaper. Project Gutenberg. https://www.gutenberg.org/cache/epub/1952/pg1952images.html.

[3] Gomez, Jewelle. (1993). Speculative Fiction and Black Lesbians. JSTOR. Signs, 18(4), Theorizing Lesbian Experience,948-955. https://www.jstor.org/stable/3174916.

[4] Habib, M.A.R. (2005). Modern Literary Criticism and Theory A History, Blackwell Publishing.

[5] Lewis, Christopher S. (2012). Cultivating Black Lesbian Shamelessness: Alice Walker's 'The Color Purple'. JSTOR. Rocky Mountain Review, 66(2), 158-175. https://www.jstor.org/stable/41763555.

[6] Pilardi, Jo-Ann. (1993). The Changing Critical Fortunes of the Second Sex. JSTOR. History and Theory, 32(1), 5173. www.jstor.org/stable/2505329.

[7] Rilke, Rainer Maria. (2016). Letters to a Young Poet, Penguin Classics.

[8] Smith, Barbara. (1978). Towards Black Feminism. JSTOR. The Radical Teacher, (7), 20-27. https://www.jstor.org/stable/20709102.

[9] Vintges, Karen. (1999). Simone de Beauvoir: A Feminist Thinker for Our Times. JSTOR. Hypatia, 14(4), 133-44. www.jstor.org/stable/3810831.

[10] Walker, Alice. (1983). The Color Purple, Weidenfeld \& Nicolson.

[11] Wilson, Bianca D.M. (2009). Black lesbian gender and sexual culture: celebration and resistance. JSTOR. Culture, Health \& Sexuality, 11(3), Contested Innocence - Sexual Agency in Public and Private Space, 297-313. https://www.jstor.org/stable/27784444.
[12] Wollstonecraft, Mary. (2002). A Vindication of the Rights of Women: With Strictures on Political and Moral Subjects. Project Gutenberg. https://www.gutenberg.org/cache/epub/3420/pg3420images.html.

[13] Woolf, Virginia. (1977). A Room of One's Own, Grafton. 